\title{
The Positive Impact of Mukhagali Makhatayev's Poetry
}

\author{
Meruyert Slyamkhanovna Tileubayeva ${ }^{1}$, Aliya Rymgazinovna Massalimova ${ }^{1}$, Maira Pobedovna Kabakova ${ }^{1}$, \\ Kulyash Esirkegenovna Bassybekova ${ }^{1} \&$ James C. Kaufman $^{2}$ \\ ${ }^{1}$ Al-Farabi Kazakh National University, Almaty, Kazakhstan \\ ${ }^{2}$ Neag School of Education at the University of Connecticut, Storrs, USA \\ Correspondence: Meruyert Slyamkhanovna Tileubayeva, Al-Farabi ave., 71, Almaty, Kazakhstan. Tel: \\ 7-870-7414-0817. E-mail: Ai_arum@mail.ru
}

Received: February 28, 2015 Accepted: March 20, 2015 Online Published: April 24, 2015

doi:10.5539/res.v7n6p126 URL: http://dx.doi.org/10.5539/res.v7n6p126

\begin{abstract}
The article presents the positive impact of Mukhagali Makhatayev's poetry. This study suggests that the usage of expressive writing, namely poetry can have a positive impact on self-perception. This review aimed to determine what is currently known about the impact of M. Makhatayev's poetry, the therapeutic use of creative writing, with a view to highlighting gaps in psychology and suggesting potential avenues of further research. This paper will achieve its aims in several ways. First, a discussion of historical paradigms that have guided the profession will be presented. Second, the nature of poetry and the poet will be addressed. Third, a historical account of poetry and the poetic in psychology and education will provide an additional historical context to the discussion.
\end{abstract}

Keywords: creativity, poet, poetry, perspective, writing creatively, self-expression, emotionally

\section{Introduction}

Poetry writing is a creative activity and, as such, may contribute to intervention. The objective of this study was to explore the impact of M. Makhatayev's poetry on individuals who had experienced personal problems in the past. Personal meaning is central to human life in symbolization processes, which contribute to identity building. Let's consider the following questions (Chart 1): 1) What is positive psychology? 2) What do you know about M. Makhatayev's creativity? 3) How does a person find out the positive impact of poetry?

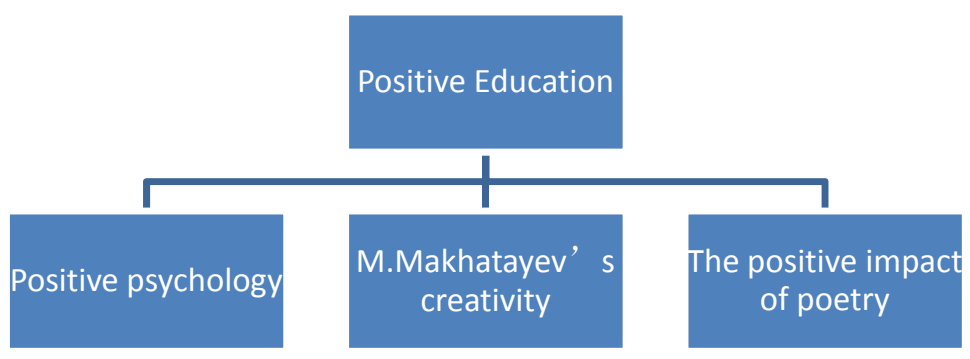

Chart 1 . The positive impact of poetry

Positive psychology is concerned with the enhancement of happiness and wellbeing, involving the scientific study of the role of personal strengths and positive social systems in the promotion of optimal well-being (chart 2). 


\begin{tabular}{ll}
\hline \multicolumn{1}{c}{ POSITIVE } & EDUCATION \\
\hline GRANDPARENTS & PARENTS \\
\hline William James (Healthy mindedness, 1902) & MartinSeligman(from 1998. APA President) \\
Rogers (Studies on fully functioning person, 1961) & Csikszentmihalyi (1998) \\
Maslow (Self actualization,study of healthy invd., & $\begin{array}{l}\text { C.R.Snyder (Journal of Social and Clinical } \\
\text { Psychology; edt.) }\end{array}$ \\
\hline 1968
\end{tabular}

Chart 2.Founders of positive education

The central themes of positive psychology, including Happiness, Hope, Creativity and Wisdom, are all investigated in this book in the context of their possible applications in clinical practice. Positive Psychology is unique in offering an accessible introduction to this emerging field of clinical psychology (Table 1).

Table 1. The need for positive psychology

It is an alternative approach to disease model as science of psychology has been far more successful on darker or negative negative sides of human but cannot explain the human condition fully. So a change in the focus of psychology from preoccupation with repairing the worst things in life should shift to building positive qualities.

Human virtues, achievable aspirations, fulfillment psychological height is as important and meritorious as the shortcomings and illnesses and distress to understand human condition.

It covers: Available resources including websites and test forms methods of measurement a critique of available research recommendations for further reading. Positive Psychology will prove a valuable resource for psychology students and lecturers who will benefit from the learning objectives and research stimuli included in each chapter. It will also be of great interest to those involved in training in related areas such as social work, counselling and psychotherapy.

The aim of this study was to analyze psychological viewpoints in Mukhagali Makhatayev's creativity and to point out the effectiveness of poetry on psychological functioning in people. A lot of people in the whole world appreciate the artistic form of communication called poetry. As far as the psychology of poetry is concerned, we could say that it has two different perspectives. The first psychological perspective on poetry belongs to the poet, and the second one belongs to the reader. Poetry challenges poets to understand themselves and their world.

Poet's perspective is related to the reasons why he/she likes to write poetry, whereas the reader's perspective refers to why people like to read poetry, why they enjoy this artistic means of expression. Creative uses of language enable us to access more complex meanings than would otherwise be the case: we draw on metaphor and other artistic uses of language "to say, paradoxically, what words cannot say" (p. 6). Flow (the state of being absorbed in an activity), a concept drawn from the broader field of creativity research (Csikszentmihalyi, 1996) has also been linked with the effects of writing as a therapeutic activity (Csikszentmihalyi, 1996). Three quantitative studies using experience sampling methods (Brand \& Leckie, 1988; Brand \& Powell, 1986; Kohanyi, 2009) found writers experienced increased and more intense positive moods while writing. Participants reported experiencing themselves as imaginative, in flow, and able to understand their thoughts and emotions while writing creatively, something that was not found to occur when engaged in nonfictional forms of writing.

Poet who described poetry in psychology was Ukraine writer I. Franko. He considered different sides of psychology. In his opinion poets are particularly people. The heart of poet depends on his genius. Desire is the most important for a poet. Poetry, which allows poets to develop a sense of wonder about their worlds (Leggo, 2009), also gives poets the opportunity to develop a new understanding of their environment and of themselves, an understanding that moves outside of a rational kind of analysis, and engages the whole self "as a feeling, thinking, speaking, sensing, and experiencing subject" (Freeman, 2001). Poetry, through its use of concrete detail and metaphor, allows us to develop a new way of knowing or thinking that can reconnect us to our 
environments.

Poetry also can be a valuable aid in understanding the experience of adolescence. Poetry has the capacity to express both affect and context, or affect in context. In autobiographical poems, poetry has the capacity to express the lived experience of the author. Poetry is personal, yet it is the goal of the poet to transform his/her personal experience into that which is universal, or in the vernacular of social research, generalizable. In this sense, the goal of the poet is to present his/her experiences, both internal and external, in such a way that the reader may enter the work as if it were their own. This notion is explored by Willis (2002) in his discussion of poetry as a tool of social educational research:

The criterion of the 'goodness' of poetry and those genres derived from it seems to hinge more on its expressive ability than its adherence to cannons of genre.

Poetry is valued as good and useful when it opens up a useful space that is shared between reader and poet. (p. 9) (Willis, 2002) Denzin (1997) advocates for alternative qualitative methodologies with the capacity to evoke emotional responses in the consumers of research. He posits that research methods must have the capacity to connect the cognitive and affective worlds of research participants, investigators, and ultimately those who read or view the findings. Poetry is utilized to explore the developmental realities of people throughout the lifespan (Denzin \& Lincoln, 1994). Furman (2003a) utilizes poetry as a means of exploring the transition from being single to step-fatherhood. Similarly, he also utilizes poetry as a vehicle to understand the importance of friendship in human growth and development (Furman, 2004).

Stein (2004) argues that poetry used in research, while not generalizable in a traditional sense, may be 'metaphorically generalizable', while poems address the experience of one person, they have the capacity to sensitize readers to existential themes that are often shared by many people (Stein, 2004). As is the case in the study we are presenting here, poetry is often utilized as a means of inquiry that is, the process of writing research poems helps the authors develop new insights. Prendergast (2004) utilizes what she refers to as literature voiced poetry as a means to 'help me synthesize, process and make meaning' (p. 75) of a literary text (Prendergast, 2004). For her, the literature-voiced poem is both a means and an end, a process of coming to grips with the nature of text, as well as a means of data representation. She states that the intention of the work is to 'transfer cognitive and affective knowledge from artist/researcher to reader' (p. 75).

Most scientists, psychologists, readers throughout the years have acknowledged the positive impact of poetry as a means to insight and healing. Indeed, many people appear to turn to poetry at times of difficulty or distress. However, despite the fast growth of poetry meetings, courses and widespread use of writing interventions in community and poetry workshops, writing has tended to lag behind other arts therapies in its development, and seems to suffer from the lack of a sound theoretical or empirical basis for its use. The aim of this review is to determine what is currently known about the positive impact of poetry with a view to highlighting gaps in the literature and suggesting potential avenues of further research.

A significant amount of the empirical evidence for the benefits of poetry for health and well-being derives from the expressive writing research paradigm pioneered by James Pennebaker and colleagues (Pennebaker et al., 1988). Their assertions that poetry is "words put together to make the reader think" and "a lot more accurate", belong to a tradition of Coleridge's "best words in the best order" (Woodring, 1990) and other definitions that focus on the conscious fashioning of words that poetry involves. As Fenton puts it, "Poetry is language to which special emphasis has been given" (Fenton, 2002). The enticement to think, brought about by such shaping and emphasis, hints at the invitations to read and, importantly, to reread that poetry can offer. And with accuracy comes compression. Mole says that poetry "uses few words to say a lot and every one of them counts" (Mole, 1994), poems give more feelings than pictures do. You have to know about poetry to be a good member of society.

The poets are in general excellent psychologists, and where the question concerns the working of their own minds they are the best. Psychology must obtain most of its facts ultimately from introspection. If then the poet's mind is to be investigated, the poets are obviously in sole possession of the most important data.

There can be various reasons why someone may like to write poetry and why people like poetry so much (or certain people, at least). Understanding these psychological issues may help one become a better poetry writer, but however, further research in this field is required in order to obtain the best results.

Self-expression is one of the main reasons why someone chooses to write poetry. Poetry is a great means of communication, allowing us to express our own thoughts, attitudes, interests, values and feelings. Indeed, poetry may be a reflection of our various interests. Another basic reason for writing poetry may be creative expression. 
Thus, poetry may be nothing more than a means of expressing one's own creativity. And by expressing creativity, we can bring meaning into our own lives.

Poetry may also be a means of expressing ourselves emotionally. We can express either positive or negative emotions. Obviously, the most frequent emotion-based poems are that expressing sadness or happiness. Writing poetry may also be a means of expressing one's feelings towards other people. For instance, people who are in love may write poems to express their feelings towards the object of their desire, i.e. the beloved person. The most efficient love poems are the ones which express one's feelings and emotions with clarity and openness.

On the other hand, as it has been previously mentioned, there are several reasons why we generally enjoy reading poetry. The first reason may be to understand another person's feelings. Thus, we could indeed say that empathy is quite similar to the appreciation of poetry. By poetry, we can understand or imagine how another person feels, and by this we can feel close to another human being. It is essential to develop empathic skills in our personal relationships, and poetry may help us do that.

Those who are interested in the more professional side of poetry are likely to appreciate it from an artistic point of view. Some people find poetry enjoyable because they are able to appreciate the writer's artistic expression. Finding inspiration and motivation, uplifting our spirits are some other good reasons for opening a poetry book. Certain poems can impregnate us with a sense of meaning and hope, or can help us gain insights on different issues.

Mukagali Makatayev was born on February 9, 1931 in Karasaz village of Almaty region. His full name is Mukhametkali. He was the first child of his parents: Suleimen and Nagiman. He was 10 when his father went to war and didn't come back from the front. He dedicated poems to his father at that time.

Mukagali Makatayev was a poet who knew psychology of his nation very well and depicted it brilliantly in his poetry. He was a connoisseur of the Kazakh soul. He described skillfully our emotional experience. Mukagali Makatayev expressed deep feelings and noble thoughts in his creative work.

The problem of my investigation is to analyze his poetry and his diary (which is about inspiration, erudition, intuition, talent or giftedness). During his lifetime, he was not recognized but after death, he reached greatness. He was acquainted with hardship and loneliness, and passed away early away at the age of 45 .

The relevance and novelty is that M. Makhatayev's viewpoints concerning psychology has not been investigated yet. There are scientific research works about M. Makhatayev's creation in other sciences except Kazakh psychology. Now we can provide a creative way to M. Makhatayev without cuts and exemptions, truly feel the drama, the tension of his quest in the society. I would like to continue research work which discloses the detailed research of the poetic creative work of Mukhagali Makhatayev in the frames of Kazakh psychological process.

The phenomenon of Mukhagali Makhatayev's artistic talent is considered as multisided and multi-directed phenomenon in the national psychology. The psychological analysis is carried out in the three aspects:

- The poetic world of Mukhagali Makhatayev in psychology;

- The philosophy of the nature in the poetic conception of Mukhagali Makhatayev;

- The lyrics of love: epic and aesthetic projections.

Ethical and esthetical parameters of the poetic picture of the Kazakh world are researched in the time-and-space projections of the artistic thinking of the genial creator. In his diary he wrote that: January 31, 1975 I cannot remember even one day, which would have left a trace of joy in my mind. That's already gone forty-fourth year, I came into this world and all life looks so insulting, so disgusting that sometimes you want to leave all voluntarily. Frankly, I haven't known before, what health is, what the disease is. It turns out that my fate did not deprive me of the opportunity in this respect. Did not know before, and now had to learn all ills. Reading Makhatayev's blogs, you realize that he is not only a great poet with a thin and vulnerable soul.

Today this name symbolizes Kazakh poetry. That's one of the last entries in Makhatayev's diary: Dear my Comrades! If you really intend to explore my biography, my work, do not forget to read anything written by me, where I was in my "I", not hiding, led a record in verse of his life. Surrender to the will of the poet and go with him to the pain, he had short and full of dramatic life's path, like a psychology reflected in his poetry. Makhatayev was born Feb. 9, 1931 in the village Karasaz, Narynkol district (now Raimbek), district of Almaty region. Sacred Beauty of Karasaz was the source of Mukhagali's poetic gift. The full name of the poet-Muhametkali, but in his childhood parents called Mukhagali affectionately, assuming that the burden of responsibility (not easy to bear the name of the Prophet) he thought also it can make life difficult for a young child. Mukhagali's parents were Suleimen and Nagiman and he was the first of three children. The Second World 
War changed everything in Mukhagali's life. He was 10 years old when his father went to the front, and all the burdens of life fell on the shoulders of a teenager. Like all boys of the war generation, he soon became an adult, realizing that in a house there were some women and children, now there was a man. Mukhagali Makhatayev debuted in print in the early fifties as a teenager. His poems included in the collection of young poets "Song of Youth" in 1951. M. Makhatayev's creativity can be divided into three periods (Figure 3).

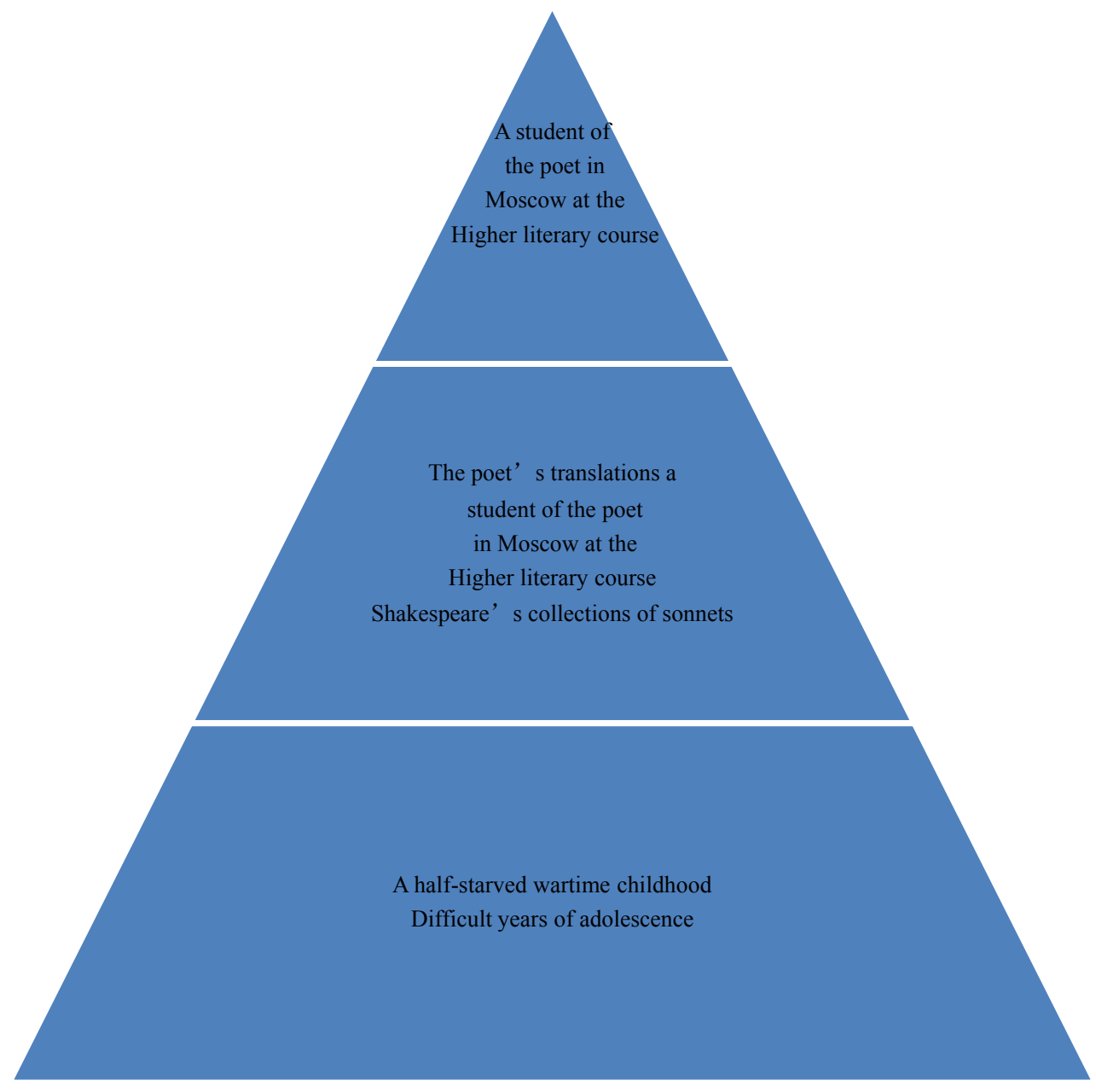

Chart 3. M. Makhatayev's creativity

The first he spent a half-starved wartime childhood. He had difficult years of adolescence. They left a deep, indelible mark on the soul of a poet. First, even children love inflicted wound to the heart, which he could not cure all his life. In the heart of the poet there's a great love for people. It is impossible to read his poems without tears.

The second period of M. Makhatayev's creativity, in our opinion-a student of the poet in Moscow at the Higher literary course on, includes the work of the poet and his translations of European classics. Collections of sonnets of Shakespeare and "Leaves of Grass" W. Whitman, "The Divine Comedy" by Dante Alighieri skillfully shifted to the Kazakh language; these translations became the property of native poetry and syllable.

The third period - a student of the poet in Moscow at the Higher literary courses and after graduation. It was a different Mukhagali. There was difficult life, there was tragic note in his verses therefore he worked a lot, published his little effort and poems that only further emphasized his love for life and people. This is already a mature Mukhagali. In those years the poet rose to the heights of his poetry. M. Makhatayev dedicated the poem Yesenin, which discloses his affinity with Russian poet ("Hey, Sergei!"). By this time, he created famous little poem "Mozart's Requiem." In this poem there were Pushkin, Yesenin and Mozart. This explains why almost identical to Pushkin's lines on a black man:

He came, someone dressed in black. "I—I order a requiem, Mozart!" 
Again he touched the piano keys, the sadness of the string passed to each other, and the sound hung, pressing on the nerves, as if life and death wept:

"We order the Requiem, Mozart!"

Mukhagali had a keen understanding of things, instinct peculiar poet enabled him to identify the most important quality of not only his poetry, but poetry in general-is present, the foundation of which is the Spirit." I want to be understood, it means people's understanding me, myself. Here it is - the essence of my poetry. For me, poetry is the cry of the soul. "I am not used to write poetry in fits and starts, wherever as anywhere. No! Poetry is impulse of the soul. When the rush, flow comes, you have to sit then work. As anyone, but I don't leave my chair, without squeezing out all the juice of inspiration. The disease is a disease, but it works perfectly. Sometimes it (creativity) heals me from all ailments" (Makhatayev, 1991). Mukhagali is original, no one else like a poet develops the best traditions of Kazakh poetry or reveals the Kazakh psychology. Real poet never dies. The Second Life of a Poet is continued. Today Mukhagali-a legend. Today Mukhagali-truth. Today Mukhagali- the Koran.

In his diary he stated: "The duty of the poet — not outline, not to describe and solve the mystery of the beauty that is hidden behind this beauty. As an experienced diagnostics, modern poet must feel the pulse of time, must be ill with the illness era of society "What is man that I am, quite frankly, I do not know. Flabby, that's true. But my soul is too good, very soft heart" (Makhatayev, 1991). Mukhagali was incomprehensible in his exclusivity, because he was very talented, perhaps even genius.

The key of learning the world, dreams and purposes of Mukhagali Makhatayev' songs is described in poem "ABC book":

Poetry could also be called an uncovered communication of souls. If during this invisible communication-reading art word is trust to us, involuntarily our soul opens. If in written except sincerity we see the purity and sublimity of thought, we have a desire to become a little better in something. As a consequence of this underlying wish our soul must do certain effort on itself in the quest to catch up to the level of spiritual development of the poet. In this case, the poet acts as spiritual "donor" and the reader with a desire to get something for their spiritual experience - as a kind of spiritual "acceptor".

If we, the readers, feel that the poet's spiritual level below our own, that the author sometimes does not understand what he is writing about, and even more if he is cunning, our soul, on the contrary, closes, and there is often a contrary intention: to roll this poet in the asphalt by truck. It is not known how the scales tend our inner confidence in hand, "I believe" or "I do not believe," because not infrequently even perfectly constructed from the point of view of logic and correct sentences instead of reader confidence for some reason only call rejection. It is possible that this process is hidden in our souls deeper than you realize. Significant role in our decision, "I believe" or "not believe" plays the fact if the poet confirms writing with his own life and whether he has any moral right to speak about what he wrote in his creations.

I would venture to make one assumption, which may, at first glance, will seem more confident for someone. Poetry (of course, on the examples of the best poetic samples with the highest concentration of thoughts and emotions) is the most powerful of all the arts, which is able to purify the souls of men to the level of the pristine purity, to cause the effect of catharsis and thus even compete with the world religions in the learning process God.

The fact of the author's thoughts with a certain level of depth often bring in readers a desire to develop the ideas brought by the author of the grains in one form or another, unconditional transfer of positive information about the author and his attachment to the name kind of "seal of quality." Overall this is a very difficult and slow process, which involves overcoming a variety of "sharp edges."

Writing and reading poetry may also help somebody feel motivated and inspired. We can write poetry with a certain message that can help us feel motivated. Another reason for writing poetry may be the wish to motivate or inspire others. Thus, it may be quite encouraging to know that by our poetry we can help others; we can bring hope or inspiration into other people's lives. Close friends encourage each other, and encouraging, inspirational poetry may be considered as some sort of letters sent by close friends.

\section{Method}

Ideas and inspiration for poetic experiments have been drawn from the Kazakh poet Mukhagali Makhatayev's creativity. First, the uses of poetry in qualitative research are explored. Second, the methodology of the study is presented. Third, autobiographical and research poems are presented and analyzed.

M. Makhatayev's poetry was translated with five students in order to test psychological comprehension of his 
poetry, at the end of which a one-on-one short structured interview was conducted.

\section{Results}

All of the students said that they benefited from the workshops, but their experiences differed greatly. Themes included competence and self-efficacy, personal growth, wanting to contribute and poetry comprehension as a way of coping with the progression of the condition. The resulting articles were screened on the basis of abstracts. The evidence suggests that a poet's creative writing may offer a range of benefits, particularly as a means of emotional processing and generating meaning from experience. For many readers, Mukhagali Makhatayev's creative work enabled them to connect to their emotions. Most students linked their engagement in creative writing with positive changes in terms of the way they saw and experienced themselves. They noticed increased selfawareness, self-acceptance, self-confidence, and a sense of empowerment. The poet is more direct in the expression, often straightforward in style, with short sentences.

Have "empathic resonance". This typical trait of the texts means that the texts inspire empathy and sympathy in ordinary people. Show the positive aspects of life: harmony, peace, gratitude, reconciliation and wisdom.

Writing, reading or reciting poetry (out loud) could indeed be some forms of self-therapy. It can be a form of escapism, or a catharsis, a means by which we purge our inner lives from the ugly aspects of the world we live in.

Based on a study of professional writers revealed the scale of individual characteristics of the poetic personality.

The positive impact of poets and poetry: A person may be affected by parameters such as:

- High level of intelligence;

- A tendency to philosophical problems;

- Originality of thought, originality and imaginative thinking;

- A wide range of interests;

- Personal independence and immediacy behaviors;

- The desire for self-expression;

- Productivity;

- Aesthetic attitude to reality;

- Skillful use of techniques impact;

- Art of observation;

- Creative imagination;

- Huge sensibility;

- Empathy;

- Sensitivity, and heightened language;

- Ease of formation of word associations;

- Feature vocabulary and sense of rhythm.

Who knows, maybe the perfect combination of these indispensable components - and have the most magical and blissful "God's gift", revealed not only poet but also a reader again

Readers of M. Makhatayev can fill their spiritual needs via his creative works. To define a poet as anyone who writes a poem is akin to defining anyone who helps people with personal problems by his poetry. After reading his poetry you feel a sense of relief, as if he steps into your shoes and makes you feel better whether he/she knows you. You can find yourself, what makes each human unique from his poetry. After reading his poetry a reader can have an ability to keep their own opinion on formation of human qualities, view of world, national education.

After reading English poet, playwright, critic, and librettist Winston Hugh Auden's line: "Poetry makes nothing happen". I reject his aphorism too. Poetry is a combination of common words, built in a special way and therefore might have a strong and unexpected reaction. This may partly explain why the highly poetic works can permanently imprinted in our memory. For me, poetry is very similar to love. Without poetry, without love, there would be the sacrament of beauty, magic transformations. Mountains without poetry-simple heap of stones, sun - a celestial body that emits heat, birds singing — as females without males, and flutter of the heart-just 
rapid circulation. Can a person imagine Mukhagali's creativity without his birthplace? No! Everything he wrote, profoundly affects each of us. A man touches the poetry becomes richer soul, for there is nothing more beautiful than the love of his native land.

- You can have a sense of self-esteem; Poets give sense to our life! Poetry represents the feelings which help us to understand our mental life.

- Of course, there is hope and kindness, pride and anger, pity and tenderness, but all of them, these concepts are born with poetry and also as poetry is born with them. People do not just read poetry, and they learn to think and develop. Poetic language - the most economical and succinct way of saying, and therefore poetry has got approval of meanings; Poet's good poems impress us as a high emotional speech, wake imagination, the whole fireworks of thoughts and feelings.

- Just try to listen, feel and understand the poetic word - it can evolve a person with pleasures of genuine aesthetic thinking.

Reading poetry gives us joy from the harmonic perfection of wit and helps to enhance mental health. Ideally, every poet deserves to be read from cover to cover-from childhood experiences to the remaining unfinished drafts.

Typically, poetry is a reflection of the inner world of artists who write about what is close and interesting for themselves. But no harm will pay attention to the psychological phenomenon of the reader's perception of the poetic works - in most cases, we tend to pay attention not to the skill of rhyming and vivid presentation, but to the fact if the poet's words are close to us the readers and if the author's experiences are the same with our experiences. The readers are as in the process of trying on the poet's "clothes of thoughts, emotions and feelings" and compare it with their own thoughts, feelings and experiences. If some author can express our feelings, perceptions of the world better than we do, a poet has a chance to get a reward label "good poet". That is, figuratively speaking, "good poet" erects invisible "framework" structure of our thoughts, feelings and experiences, leaving a small amount of work for our imagination: to paste over this "framework" inside "wallpaper" on your own taste. Thus, with some caution we can talk that poets are like the "pioneers", creating an ephemeral "home" for the restless souls of readers looking for rest or something more sublime than that with which we have to face in everyday life.

We do not have compelling answers on this and many other questions yet. The only thing that had to repeatedly convince: poetry in fact is an inexplicable miracle that changes and transforms the inner world of the poet and the reader.

In fact, all human life is a kind of school, and each of us resides at different steps of the study in this school. Time-tested sincerity gives the genre of poetry very good chance to get the reader's trust and the only "teacher-competitors" in this regard is perhaps religious teachings. Poetry can be called wise, but unobtrusive adviser, who can in confidence-readable form accessible to reveal different facets of everyday and philosophical maxims. Connection of various semantic, emotional, melodic, and other layers of poetic language can very effectively and rapidly discard the blinders from our childish mind.

By turning us into creators, poetry connects us to our internal resources and changes our point of view. And even if poetry is not always a veil that could help us camouflage all the bad and ugly things in this world, it can still help us transcend them and can make us more conscious.

\section{Discussion}

Every Kazakh person without doubts knows popular poet Mukhagaly Makhatayev. His poems which inspired to my mind therapy help in school days prove that he was not only psychological professional also he was professional of knowing Kazakh people's spirit. And in result of everything I decided to prove that Mukhagaly Makhatayev was a professional poet. His ability and talent were unique. Let's turn to his poem:

Dear,

I'm neither Lermontov nor Pushkin

I am and I have told nobody that I am Esenin

Kazakh folk verse-is the power

There is a terrifying, unprecedented secret (Makhatayev, 2009).

Makhatayev's all poetry - a harmony of love and creative sense, which reflects the personality of the poet.

What is the homeland for Makhatayev? The answer can be found in the poem "My Motherland". Spirit and culture, language and history, the amazing beauty of the earth and talented people - this homeland. Kazakh land 
is alive because it's always guarded by the great Kazakh sons, to whom the poet bows his head. He is happy and proud to have been born on this earth. "So affectionately calls people from his country" my people, baby. "With warmth and said them: "My good-natured people." People-his protection and support, his castle, "My House-My people." The poet cannot live without them. "The fate of you I do not worry, Give heart to heart, talk with his people!" It is the people who truly understand and appreciate the poet. And the relationship between them is inseparable: "Your voice with me, your songs, your thoughts are with me Wherever I go." Record of March 20, 1973 contains reflections of the poet that friends and comrades are spreading rumors about him a lot, sometimes embellishing the facts and putting a twist. This human weakness he is condescending: "Let them talk." Makhatayev by nature was a man of delicate, so two things in life given to him with great difficulty. Firstly, it was humiliating to expose human dishonesty, and secondly, to refuse to say "no." And maybe it was the main cause of suffering poet. "Soft-hearted - my weak point. Probably because of this, I often stumble."

There are a lot of branches of psychology. The branches which belong to our today's topic among them are: therapy of art, therapy of poetry. While I was exploring poetry I noticed that foreign scholars used the poetry as a cure. Generally how did they use the poetry? The question disturbed my mind. As a professional psychotherapist one listens to another's wounded spirit using poetry on interview. The poetry develops the right sight of brain and sensitive creative sides too. Our emotional and mental problems are spot of the spiritual wounds from childhood. It will be felt during emotional pain .We try to forget them. But to the end of everything they will be left in our thoughts. The way of forgetting problems is to break negative energy and recognize them. You must identify the pain. We can notice our mental fantasy while we are using words and are dividing sensible. The poetry directs its aim straight into two fancy: they are emotional and mental. If somebody can't feel feelings he doesn't live with pleasure.

"ABC book-is the book of all books, top of knowledge" and this was the call for young children to get education, strive for knowledge, it was his direction for future.

$\mathrm{He}$ acted as a corrector of education-training tendencies in formation of physiological qualities of rising generation. During the period of formation of youth as individuals, he becomes an author of a great work. "This is-your school, your grade" (Makhatayev, 1999). Place where you will get education. You will enter here as a "grain" and will exit as a "mountain"- that is how he disclosed the deep meaning of close tights between education and training. He opens for young generation a mystery of their life route from their first undertakings up to their complete formation as individuals.

Man - a child of nature and he should try to learn about the nature more and develop his view point by understanding himself as an individual and participating in life of society. One of Makhatayev's contemporaries said: "The heart of the great poet was like a clean child". Kind and sincere, humble and bold, naive and generous, open and simple, straightforward and fair, so often said: "People are born to understand each other and live in peace."

Author nurtures for persistence, consistence, and activity in young generation the love. He pays special attention to mindset of rising generation, love for nature and calls to study it, study ourselves as individuals, calls to know that our thoughts and actions directed at an object are tightly interconnected.

Education prepares a child for labor and during education for major teaches to produce material and cultural values. Labor activity of a man in society plays important role in nurturing a child as an individual.

Labor - is action directed at production of useful products and things that satisfy material and spiritual needs of man. Labor changes man from spiritual and physical side, forms positive qualities of man. Man achieves the set goals only when puts new requirements to himself. It influences on psychological peculiarities of formation of child as individual and also influences education of rising generation. To find our niche in society is possible at participation not of a separate person, but several persons. Thus, though general education each man gives a child possibility to find own place in life.

Mukhagali Makhatayev in his poetry leads youth to persistence in everything, calls for freedom. "Youth is put for battlefront, but do not grieve in such a sunny day, be delighted anyway!", - encourages young people. According to critics, words of Abay "Eating plenty, lack of work - is what perverts a man" indicates that we feel regret only after we while away the time. Nurturing point of view of poet is especially expressed in his poem "February". "Laziness - is a bad quality; it will not grow even a twig. Education and labor, rest—all together comprise our life" - this is the way the author calls for spiritual advance through training oneself to labor, getting knowledge, improving skills.

The important place in education of a child will take a poem "My kid! Old man is coming". These lines mean 
that we predict our future by looking back to the past of our ancestry. For formation of awareness, mind of rising generation the importance influence is given in wisdom advices of older generation that have lived though, and seen a lot. "Turn your head to exhausted old man" (Makhatayev, 2009).

Here we understand the meaning of words on respect and humanism. Lines: "My kid! Old man is coming" say us that we always should frankly respect them. "Wise old man is like a flowing river" say our people.

By early 1972, Makhatayev had already lived in Almaty for ten years. At this time, he had the glory, which played an important role in the early death of the poet.

Complexities of material life cause people to get alienated from each other, cause misunderstanding. The poem "We concede" tells us that we understand importance of friendship when share hardship of our friend who encountered difficulties in life. "Anything you encountered-we will meet with dignity. Show me your sorrow-share it with me! We will encourage each other". In this poem the author directs us to kindness by showing us the real friendship.

The "Happiness" poem pictures happy days of childhood. In his diary he suggested that: "Poetry, beginning with love, must end with reflections" Makhatayev Diary Almaty Publishing house "Zhalyn" (Makhatayev, 1991).

Whenever you read Mukhagali's poetry, it is always fresh. We are continually seeing new depths and nuances of meaning. Let's turn to his poetry: Farewell to Pushkin (Makhatayev, 1993).

"We are free birds to fly, brother, it's time".

\section{Prisoner,}

Well now let's say goodbye to each other brother flagship.

Tomorrow I will fly to my yellow steppe,

Strength of an eagle - is in the vast steppe,

Strength of the eagle is only in the mountains.

Tomorrow I will fly to my yellow steppe.

For now, good bye, brother-flagship!

Do not criticize, do not take offense at the son.

Poetry of a poet is not in-a title,

Poetry of a poet — is only in an honor.

It is true that writing extends this niche, and requires further adaptation, which starts with learning to write and read.

M. Makhatayev directs us to understanding of improvement of humanism, widening our mental outlook, showing respect to worlds of older people. Poet calls youth and rising generation to humanity, prudence: "with the name of Allah my heart is beating faster, Allah is truth, please believe in Allah"- in these lines the author asks us to live with trust in Allah and honesty. And in further lines he says: "The Creator-my only master, direct your rays to us"- -speaking of deep understanding of meaning of life, kindness towards people. In his diary he pointed that Poetry - Science. If there is a force that investigates human feelings fully, it is - only poetry.

M. Makhatayev is the most gifted poet, owner of a great talent. Sometimes people did not understand him. It is also true that M. Makatayev takes a special place in the heart of our people. His each poem was written from heart. But we understand "talent" was ability to quickly write a poem without any deep meaning. As Democritus said, the true talents always full of sorrow. Great poets often were not understood by the society during their lives. It is hard for a poet to get along with society and sometimes authorities do not like poets. M. Makhatayev depicts us the general image of Akyn, his personal gifts, his spiritual inner worlds and his character.

The current study is the first to carry out an in-depth, participant-centred analysis of the subjective experience and understandings of individuals who had engaged in creative writing at times of personal difficulty, using first-hand, and written accounts. It seems that M. Makhatayev's poetry in the context of adverse life experiences enabled people to regulate distress, gain insight and acceptance, and to connect in a more meaningful way themselves, others and the world around them. This analysis suggests that reminiscence-based poetry interventions can be used to restore personhood, by helping those who care for them to understand their unique personal histories, and to appreciate the rich social and emotional lives these individuals are able to live and to cope with personal difficulties. The account sheds light on some of the processes which may underlie the therapeutic benefits that have long been associated with the poet's creative writing, and suggests links with existing theories. 
When the spring is rampant,

When there is heavy rain,

When there are rumbling clouds,

Pierces are lightning.

Remember me.

When there are the floating light clouds,

When you find yourself in a summer forest,

Dream about me, dream!

When you stay alone,

Remember me.

When October comes,

When the gardens are dressed in purple,

Trees sadly sing,

When leaves fall from trees,

Remember me.

When the white snow covers the earth,

When the trees are dressed up,

When it's gray February,

Pale dawn,

Remember me!

Think about me! (Makhatayev, 1991).

Mukhagali wrote also explicitly about the natural environment that surrounds him. And that poetry is always up to date and always lives in the world, which the poet loved. He had a source of knowledge or an existential dimension of truth. He used a variety of techniques to begin to understand the hidden meaning of a reader's words. Makhatayev's happiness is to live in his own country with his people. How many in this noble and true patriotism! Inexhaustible love of the poet to his native land, his people deeply touches the soul. True-we have something to learn from Makhatayev!

\section{Conclusion}

Positive aspects of human are seriously neglected by the discipline of psychology which otherwise would have provided invaluable knowledge and guideline for the young generation for personal and social wellbeing. Creative activities such as poetry hold promise for enhancing people's quality of life. The effect of Mukhagali Makhatayev's poetry on the readers was considerable. They described strong and painful feelings and thoughts. There is a need for more rigorous qualitative studies to be undertaken in this area to address significant gaps in the evidence base. Several potential areas for further research have been identified through this review.

The current study looked at the experiences of people who used M. Makhatayev's poetry at times of personal difficulty. It was deemed to have played an important and meaningful role in helping participants to integrate and move beyond difficult life experiences. Poems mark a glimpse of an emergent, more emancipated way of living and relating, where the poet's directness and courage allow for interpersonal spaces not ideologically controlled. His poetry permits us to rediscover not only where but also who we are and a new understanding of our local environments to occur. It achieves this new understanding not only through analytic reason, but also based on the sensual feeling and experiential aspects of ourselves. Mukhagali Makhatayev lived a short, but bright, hard, full of creative life. M. Makhatayev's poetry is alive to the texture that surrounds and constitutes our lived experience. While the poet strives to create a personal meaning for herself, she also seeks to illuminate meanings to and for others. So too, the poet seeks to maximize an individual's self of meaning in the world. The insights that can be discovered in the therapeutic process are similar to the insights one gains while writing poetry. This is a small study and the findings are valid only in the immediate context of study but it provides a basis for further research. 


\section{References}

Brand, A. G., \& Leckie, P. A. (1988). The emotions of professional writers. Journal of Psychology, 122(421), 450. http://dx.doi.org/10.1080/00223980.1988.10542948

Brand, A., \& Powell, J. (1986). Emotions and the writing process: A description of apprentice writers. Journal of Educational Research, 79, 280-285. http://dx.doi.org/10.1080/00220671.1986.10885692

Csikszentmihalyi, M. (1996). Creativity: Flow and the psychology of discovery and invention (p. 350). New York: Harper Perennial.

Denzin, N. K., \& Lincoln, Y. S. (Eds.). (1994). Handbook of Qualitative Research (p. 120). Thousand Oaks, CA: Sage.

Fenton, J. (2002). An Introduction to English Poetry (p. 250). London: Penguin Books.

Freeman, M. (2001). Between eye and eye stretches an interminable landscape: The challenge of philosophical hermeneutics. Qualitative Inquiry, 7(5), 646-658. http://dx.doi.org/10.1177/107780040100700508

Furman, R. (2004). Using Poetry and Narrative as Qualitative Data: Exploring a Father's Cancer through Poetry. Family, Systems and Health, 22(2), 162-170. http://dx.doi.org/10.1037/1091-7527.22.2.162

Kaufman, J. C., \& Kaufman, S. B. (Eds.). (2010). The psychology of creative writing (pp. 41-56). New York: Cambridge University Press. http://dx.doi.org/10.1017/CBO9780511627101

James, C. K. The cost of muse: poets die young.

Kohanyi, A. (2009). The more I write, the better I write, and the better I feel about myself: Mood variability and mood regulation in student journalist and creative writers.

Leggo, C. (2009). Poetry of place: A review essay. International Journal of Education and the Arts, 10(8), 1-7. Retrieved from http://www.ijea.org/v10r8/

Mole, J. (1994). Questions of poetry. Signal, 74, 86-92.

Mukhagali, M. (1993). Almaty (Vol. 3, p. 344).

Mukhagali, M. (2009). Almaty (Vol. 4, p. 320).

Mukhagali, M. (1999). A swallow from Karasaz Almaty Publishing house "Zhalyn” (p. 224).

Mukhagali, M. (1991). Diary Almaty Publishing house "Zhalyn” (p. 49).

Pennebaker, J. W., Kiecolt-Glaser, J. K., \& Glaser, R. (1988). Disclosure of traumas and immunefunction: Health implications for psychotherapy. Journal of Consulting and Clinical Psychology, 256, 239-245. http://dx.doi.org/10.1037/0022-006X.56.2.239

Prendergast, M. (2004). Shaped Like a Question Mark: Four Poetry from Herbert Blau's. http://dx.doi.org/10.1080/1356978042000185920

Stein, H. F. (2004). A Window to the Interior of Experience. Families, Systems, and Health, 22(2), 178-189. http://dx.doi.org/10.1037/1091-7527.22.2.178

Willis, P. (2002). Poetry and Poetics in Phenomenological Research. Indo-Pacific Journal.

\section{Copyrights}

Copyright for this article is retained by the author(s), with first publication rights granted to the journal.

This is an open-access article distributed under the terms and conditions of the Creative Commons Attribution license (http://creativecommons.org/licenses/by/3.0/). 